\title{
WATER UTILITY INTEGRATION IN HUNGARY: IMPACTS AND FUTURE EXPECTATIONS
}

\author{
KÁROLY KOVÁCS \\ PhD student, Faculty of Business Administration, Corvinus University of Budapest \\ President, Hungarian Water Association (MaSzeSz) \\ E-mail: kovacs.karoly@bdl.hu
}

In 2011 Hungary's water supply and sanitation sector was characterized by a multitude of utilities, a fragmented market with widely differing tariffs and no centralized regulation, resulting in often inefficient and unsustainable operational and market conditions. In 2011 the Hungarian government introduced the Act CCIX of 2011 on Water Utility Services which resulted in significant market consolidations. In this article we present the results of a qualitative survey carried out in 2015 to examine the opinion of top managers of utilities on the short and midterm effects of the realization of the objectives set by the Act. The interviews focused on examining the efficiency changes experienced by 15 CEOs of different water utility service provider companies since the integration. The paper also examines their expectations for the future across a multitude of technical and economic fields and factors. This qualitative research aimed to study whether the recent changes in policy and market structure led to economies of scale and to the perceptible increase of technical and economic efficiency levels. It was concluded that efficiency benefits of economies of scale prevailed in most cases, however, these were perceived only to a limited extent at the time of the survey, approximately midway through the ongoing integration processes.

Keywords: water utility management, market integration, water infrastructure, water supply and sanitation, utility law, economies of scale

JEL-codes: K23, O110, H830 


\section{INTRODUCTION}

The purpose of this paper is to analyse the short and midterm impacts of the Act CCIX of 2011 on Water Utility Services, its effects and their perception in the Hungarian water utility sector. In 2010, the centre-right government of Viktor Orbán came to power and started its activity by transforming the overall legal framework of the country, beginning with the constitution, followed by the introduction of many new sectoral and nation-wide legislation. The government has applied an unorthodox economic policy in order to break away from the former government's austerity policy, "restart the engines of the economy" and restore the country's fiscal and economic stability torn by the 2007 crisis (Bod 2012). The evaluation of the activity of Orbán's cabinet is controversial in the political discussions as well as in the literature; however, this paper is not intended to provide such an evaluation or reasoning for either opinion. What is relevant and important from the point of view of the water utility sector analyzed in this paper is the general intention of the government to strengthen state presence, centralized control and to protect presumed or real national interests, which is characteristic of all of their measures, including Act CCIX of 2011 on Water Utility Services (hereinafter referred to as "the Act").

As a result of the Act, the Hungarian water industry has undergone significant changes in the past few years. The Act significantly delimited and confined private ownership in the sector and led to a substantial market consolidation, whereupon the number of water utility providers shrank from 400 to 47 by 2015 in the frame of the gradual implementation of the Act (Szalóki 2015).

The purpose of this paper is to analyse the short and midterm impacts and their perception on the recent integration of the water utilities in Hungary; and to investigate the opinions and expectations of top managers of the utility service providers. This qualitative research aims to establish whether the recent changes in policy and market structure led to economies of scale and to the increase of technical and economic efficiency levels.

The hypotheses of the paper are the following: The integration of the water utility suppliers and the consolidation of the market result in:

- H1: the improvement of economies of scale and cost efficiency,

- H2: the improvement of service quality,

- H3: more transparent operation, which will in turn lead to better management and monitoring.

It is argued that these hypotheses are in accordance with the hypotheses of the policymakers and decision makers supporting the Act on Water Utility Supply. 


\section{INTERNATIONAL OUTLOOK ON WATER UTILITY EFFICIENCY MEASUREMENT}

The determination of causes and the measurement of economies of scale and efficiency levels in the water industry are topical issues. During a study conducted in Brazil, where 20 water and sewerage utilities were observed between 1996 and 2000, Tupper and Resende (2004) calculated whether efficiency levels in the Brazilian water sector were influenced by structural and/or quality variables. The result of the study showed that only water losses and network density have a substantial impact on efficiency levels. García-Sánchez (2006) used a four-stage parametric analysis to determine the technical and scale efficiency of 24 Spanish municipal water suppliers with treatment plants, staff and network length as the inputs. He found that network density had a major impact on efficiency. Renzetti and Dupont (2009) found that when accounting for the environmental factors in the technical efficiency of 64 Canadian water service providers, elevation differences, population density and the ratio of residential water compared to the number of private dwellings had a substantial impact on efficiency. A recent research into the performance of German water utilities found major variances in technical efficiency, an indication of the potential for cost savings and consumer price decreases. Furthermore, they found that small water utilities were outstandingly inefficient, which raises questions with regards to suitability of such firms' supply structures (Zschille and Walter 2012).

These studies all took a quantitative approach to analysing technical efficiency differences, applying different methods of Data Envelopment Analysis (DEA) and Stochastic Frontier Analysis (SFA). This paper takes a qualitative approach towards determining whether the executives of the water utility suppliers perceive the positive effects of economies of scale; and aims to gain insight into their current and mid-term future outlooks on economic and technical efficiency levels. The reason for this approach, on one hand, is that their expectations and perceptions play a fundamental role and have a significant influence on the extent to which the benefits of economies of scale prevail and lead to real cost efficiency improvements. On the other hand, due to the ongoing restructuring of the utility companies, it is hardly possible to gather actual, reliable and comparable data regarding the regularly used quantitative indicators of cost-efficiency. 


\section{THE HUNGARIAN WATER UTILITY SECTOR BEFORE THE ACT CCIX OF 2011}

Before 2011, the existing legal framework of the water utility sector was as fragmented as the market structure. There were no centralized, coordinated regulations in place, and many different institutions exercised legal authority over the industry (Act LVII. of 1995; Act LXXXVII. of 1990; Act XXXIII. of 1991). The fragmented legal environment often resulted in situations where the overlapping or missing regulations and principles hindered decision makers in choosing the right practices. There was no central register for water service providers, and the provision of water utility services was not subject to permission. Because of this, situations arose where the power for setting water service tariffs belonged to the government (for five state owned regional utilities), but mainly to local authorities and municipalities (for most settlements), who were price-regulators, consumers and owners at the same time. Thus, water and sewage prices were significantly influenced by the different interests of local representatives and politicians. This often resulted in inadequate tariffs that failed to cover all the costs of service provision, especially the necessary reconstructions and maintenance. These conflicting roles led to the adaptation of short term viewpoints and goals, which in turn resulted in no available savings for reconstruction of the infrastructure, a backlog of investments, tariffs not even recovering operational and maintenance costs. On most smaller utilities and settlements household tariffs were below commercial tariffs, and the implicit life expectancy of assets were on average a 100 years or even more based on investment activities (Kaderjak 2014).

These circumstances led to uncertain conditions in the water utility sector and resulted, on the long term, in extreme differences in both quality and prices of the service, as well as in the declining technical condition of the infrastructure, causing social tension in many cases.

The transformation of the Hungarian water sector began on the 30 December 2011, when the Hungarian Parliament adopted Act CCIX of 2011 on Water Utility Services. The main purposes of the new regulations were to settle the ownership of water utility assets and to clarify the exact terms and conditions of water utility service provision. The Act strengthened public ownership in the sector. The infrastructure itself, the water utility assets must be state or municipality owned and only the so-called "operating assets" (office buildings, computers, vehicles, etc.) can be owned by the company, which needs to keep separate records of these assets. This is one of the major measures of the Act. Before 2011, there were both infrastructure and utility companies in private and/or in foreign ownership due to the inconsistent regulation, permanently insufficient funding of municipalities 
and to concession contracts for service provision, for example in case of the Budapest Water Works, Budapest Sewage Works and Pécs Water Works.

The Act also defined three contractual forms of service provision between the owner of the infrastructure (state or municipality) and the service provider company: asset management agreement, operating and leasing agreement and concession agreement. The first two contractual forms can be used only in case of fully state and/or municipality owned service provider companies, meaning that both the company and the infrastructure are in public ownership. Concerning the concessions, all of these contracts have been closed before their original concession period with only one exception that is still in force. Untimely closure of these agreements was not a requirement of the Act, but initiated by the state or the relevant municipality following the general political intention to strengthen state power and protect national interest.

According to the Act, The Hungarian Energy and Public Utility Regulatory Authority (HEA) became entitled to supervise the water utility sector. The HEA, which was originally established by the Hungarian Parliament in 1994 under a different name, is an independent, multi-sector regulator with a separate budget. HEA is responsible for licensing, supervision, possible regulatory benchmarking, price and tariff preparatory tasks and is also responsible for approving the "rolling development plans" (Szalóki 2015).

Description of further characteristics of the Hungarian water utility sector is included in the following section where appropriate.

\section{ANALYSIS}

\subsection{Research method and results}

In order to gain knowledge and information on the expectations and experiences of the executives in the water utility sector in Hungary, a survey was carried out in 2015. The survey consisted of 14 qualitative and quantitative questions. The questions focused on the issues of everyday operations as well as development strategies: The majority of the questions were open, requiring qualitative evaluation of certain aspects of water utility management, supplemented by a few quantitative questions about the main figures of the services (total length, water consumption, etc.)

The survey was sent out via email to the managing directors and heads of Hungarian water utility companies. Over the span of two weeks 15 responses were gathered. Although the response rate was relatively low, the results are 
still considered to be appropriate and worthy for analysis, mainly because of the realistic assumption that those who have answered the survey are the ones who have the best insight on the issue. This is also supported by the fact that none of the respondents chose the "I do not know" answer for either question, although this option has been offered at each question where applicable. Therefore, the results of the survey are considered positively biased, showing a slightly better picture on the issue than the reality.

In the cost management and efficiency improvements question category, 77\% of the respondents reported some kind of improvement in HR management and in the administrative operations, and $60 \%$ in the engineering/technical monitoring systems. Eighty percent reported efficiency improvements in the field of integrated and optimized management of materials, maintenance and troubleshooting. Seventy-nine percent of those who responded claimed that their integrated water utility asset management with regards to operating assets became more efficient since the market integration. The minority of the respondents, around $7 \%$ perceived major efficiency improvements in the above mentioned fields and categories.

Eighty-six percent of the respondents perceived efficiency improvements when it came to cross-subsidies flowing out of the industry, $29 \%$ of them reporting a large efficiency improvement in this field. Ninety-three percent of the survey participants claimed a cost efficiency improvement in integrated procurement opportunities in the major cost factor products and services (e.g.: electricity). Fourty percent reported major or large efficiency increase. Sixty-four percent of the managers completing the survey observed an efficiency increase during the integration of the technical supply systems.

To the question 'How has the overall cost-efficiency of the company's activities (without tax effects) changed compared to 2011?', 67\% reported an improvement in the efficiency of the overall activities and $27 \%$ said it worsened. Comparing this to the previous question category where the survey for answers did not offer an option for 'worsening', only several stages between 'no improvement to major improvements', one can conclude that those respondents who fall into the categories of those who reported no improvements, between $20-35 \%$ on average per question, could have very well meant that the operational and cost effectiveness worsened since the integration.

The cumulative impact of the above mentioned issues ranged between a 5 to $8 \%$ efficiency improvement, reported by one company, to a $12 \%$ deterioration reported by two companies. The majority of the respondents $(53 \%)$ observed a $3-5 \%$ cumulative efficiency improvement.

Projecting forward, in 3-5 years, after the payment of the one-time transaction costs, the majority of the companies expected some kind of cost efficiency im- 

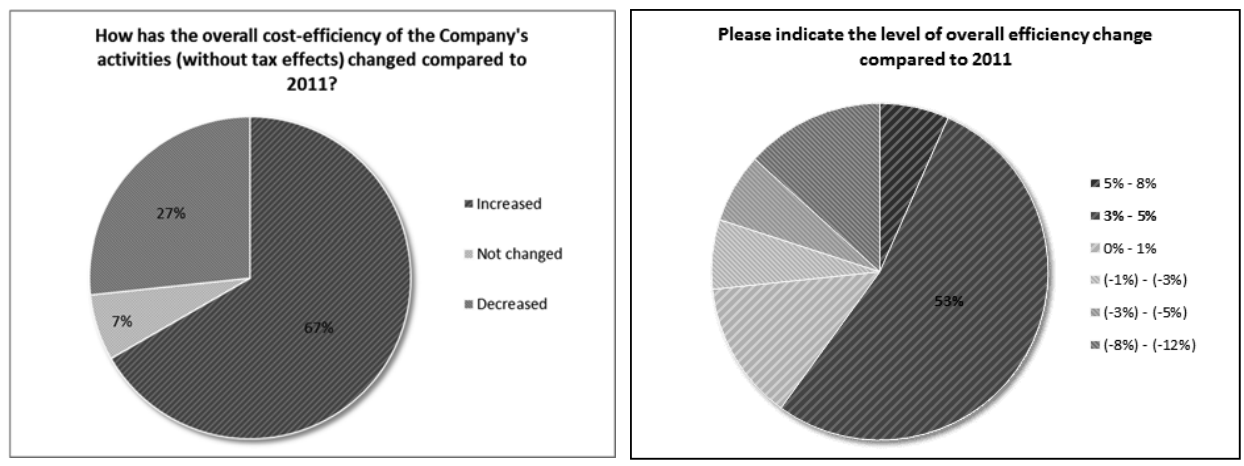

Figure 1. Overall efficiency change since 2011

Source: author.

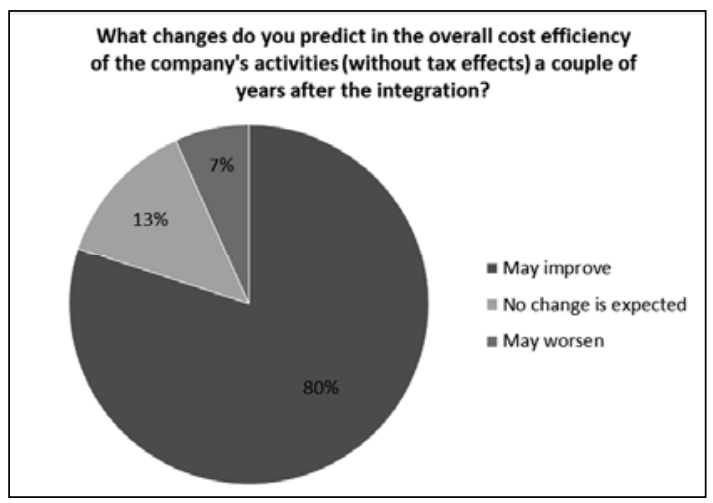

Figure 2. Expectations regarding overall efficiency changes

Source: author

provements compared to the current situation. The most significant improvement was expected to happen in the field of HR management and in the administrative operations. Eighty percent predicted an overall cost-effectiveness improvement of the company's activities (without tax effects) in the couple of years after the integration process and only $7 \%$ said that it would likely worsen. However, the expectations about the fields and magnitude of these future improvements were rather diverse; respondents had varying opinions with regards to this.

When asked to indicate the challenges experienced during the integration in the different fields and activities by the suppliers, the majority of the respondents said that the elimination of technical non-compliance caused major issues, along with the integration of the service fees and costs of the integrated areas 
into the existing fee and cost structure, and the integrated usage of replacement and renovation resources. The fewest problems and challenges were experienced in the integration of customer service operations; only $20 \%$ indicated some challenges here.

In terms of service quality indicators; $60 \%$ of the suppliers experienced a deterioration in the quality indicators of potable water, while $33 \%$ indicated that these indicators improved compared to 2011. Fourty percent of the respondents claimed an improvement of the quality of treated wastewater with the same amount of suppliers reporting deterioration. Overall there was deterioration in service quality in terms of complaints handling, trouble shooting and the duration of service outage and frequency. This was to be expected as four years after the passing of the Act on Water Utility Services the changes and integration was still an ongoing process.

Responses on the questions concerning the asset values, asset management and reconstruction funds were quite similar. The extent of the funds available for utility asset reconstruction/replacement types of investments compared to the revenues collected from water tariffs is $25 \%$ or more in case of only one company. This ratio in case of the majority of the suppliers is below $10 \%$, with almost one third of the companies reporting available funds for reconstruction and replacement to be around 0-5\% compared to the revenue from tariffs. For comparison, this ratio at Swiss water suppliers is about $60 \%$ and over $50 \%$ for German ones (IDEA 2013)

Two thirds of the providers expected or experienced an over $100 \%$ growth in the book value of their assets as a result of the water utility asset evaluation process mandated by the Act on Water Utility Services 2011.

When asked about the future opportunities and challenges, most respondents had positive and negative responses as well. Many referred to the opportunities with regards to more efficient capacity utilization, the positive effects of centralized automated data provision, the decrease in bureaucracy, and the improvement of transparency. On the other hand, utility providers raised concerns regarding the issues of the technical integration of the supply systems and some further rationalization of business processes, and the financial and investment challenges.

\subsection{Market integration as a result of the Act on Water Utility Services}

As a result of the Act on Water Utility Services, each water service provider was required to apply to the HEA for an operating license. In order to obtain it, applicants needed to fulfill strict requirements, one of which was a minimum service volume. In order to receive an operational permission, suppliers needed to demonstrate the ability to meet a minimum of 150,000 consumer equivalent. 
The calculation of consumer equivalent is defined by Annex 1 of the Act and it takes into account residential, institutional and industrial users as well, providing a unified indicator of service volume. Transitional regulations of the Act have secured a stepwise integration process. By 31 May 2013, water service providers had been required to present at least 50,000 consumer equivalent, and by the 31 December 2014 this number increased to 100,000 , reaching the final volume of 150,000 consumer equivalent by 2017 .

Before the Act, one could see a fragmented and diverse water utility market. The size of the service provider companies varied greatly. There were several large companies with vast service areas and a large number of small firms providing water services only for one settlement or two. Approximately 99 companies out of the 400 provided $95 \%$ of the water services for the population, the ten largest firms provided $60 \%$, and the three main ones were responsible for $40 \%$ of the total water supply of Hungary (Ungvári - Koskovics 2011; Kaderjak 2014). The structure of market was fragmented and concentrated at the same time. It was inefficient and not sustainable. Among the above mentioned larger suppliers were the two water firms of Budapest (Fővárosi Vízmüvek, Fővárosi Csatornázási Müvek) and the five regional, state owned water service providers (Tiszamenti Vízművek Zrt., Északmagyarország Regionális Vízművek Zrt., Duna Menti Regionális Vízmű Zrt., Északdunántúli Vízmü Zrt., Dunántúli Regionális Vízmü Zrt.).

Since the adoptation of the Act on Water Utility Services, hundreds of small companies have either merged to fulfill the new requirements or vanished entirely from the market. However, the integration process was not yet complete at the time of the survey and further changes were expected in the industry to meet the required minimum amount of consumer equivalents by 2017. Currently, the average population size served by a company is more than 200,000 , which is one of the highest values compared to other countries in the Central and Eastern European region (The World Bank Group 2015).

In total, from originally more than 400 service providers, during the 20132014 market integration, 84 water utility suppliers handed in an application and 47 of these were granted an operational license (Szaloki 2015). In 2017, 42 companies were operational, due to further mergers and termination of companies since our research.

\subsection{Tariffs of the water services}

Before 2011, the tariffs of drinking water service and wastewater disposal were determined by the municipalities or the government. As municipalities had the authority to set water and wastewater tariffs, there were more than ten thousand 
different water and wastewater tariffs in use on the Hungarian market (considering 3,500 municipalities, water and wastewater service, household, industrial and other consumer groups). There was a 23 -fold difference between the highest and lowest tariffs, which is mostly a result of the fragmented feature and inconsistent regulation of the market, and only explained partially by the different hidro-geographical circumstances of operation. Principles of solidarity and cost recovery could hardly prevail in the tariff system before the Act. Complete harmonization of water prices is not desirable from any point of view, but within a big enough water utility service provider company, supplying several smaller and bigger settlements with different efficiency, network density, geographic and technical characteristics, etc., there could be opportunities to enforce solidarity and cost recovery principles in the price system. So lower cost areas could balance out less efficient systems, while maintaining total revenue level and better meeting affordability limits of the consumers, especially low-income groups living in small villages, as well as easing social tension in general.

According to the Act, the Ministry and the Minister of National Development determines the tariff of water services. The decision is based on the detailed pricing proposal prepared by HEA. The Minister has not issued an implementation decree on price setting until mid-2017, however, the tariff system has been centrally altered on two occasions. Firstly, due to Act CCIX of 2011, the increase of tariffs capped at $4.2 \%$ of gross prices on 31 December 2011. Two years later, in mid-2013, the Utility Cost Reduction Program was applied to the water sector as well, as part of the government's push towards lower utility prices for better affordability and improved competitiveness of Hungarian economy.

As a result of this, all utility tariffs were uniformly reduced by $10 \%$ compared to 2012. To summarize the changes, one can say that in spite of the new central mechanism of setting tariffs, the level of the service prices still show a huge variety in different locations. The alteration of the tariff system only decreased all prices, but did not lower the differences between them. This leads in most cases to the lack of cost recovery achievement. There is a strong pressure on utility providers to increase operational and cost efficiency, while delaying infrastructure reconstruction investments (Kaderjak 2014).

\subsection{Employment}

There were over 18,000-20,000 people employed in the industry in 2011. This is 5,000 jobs fewer than what was provided by the water utility sector in 2000 (KPMG 2015). Horizontal integration usually results in staff reduction due to a more lean approach to operations in order to gain the most from the increase of economies of scale. However, in this case, the numbers do not show this effect. 
On the contrary, the total employment had increased by $8.4 \%$ from 2011 to 2013 , which meant more than 1,500 new jobs in these 3 years (KPMG 2015).

This trend can be explained by two causes. Firstly, wastewater disposal services have been regionally expanding, adding new household connections to the network resulting in the creation of new jobs. Secondly, the water utilities did not use the integration process for rationalizing their employment structure. In most of the mergers, they just automatically took over all the employees of the former companies. In the survey discussed earlier, a majority of suppliers indicated some level of experience and expected efficiency improvements in both the operational and administrative, as well as in the technical supervision areas.

\subsection{Financial performance}

Before the start of the integration process, the Hungarian water utility sector had showed a stable economic state with only little changes in the annual business indicators. The tendency of aggregated revenues of the sector had been slowly increasing (between 2009 and 2011 by only $5 \%$ ) and the profit was around 14 billion HUF in the last three years before the integration process. In 2011, in the last year of the old system, the aggregated net sales revenues of the sector were 251 billion HUF and the operating profit was over 14 billion HUF (KPMG 2015).

It is difficult to separate the economic effects of the integration from the other changes related to the recent regulations, such as the Utility Cost Reduction Program and the Utility Infrastructure Tax that were introduced in 2013. These have a major impact on the financial state of the water service provider companies, and resulted in the deterioration of the efficiency of the sector. As a result, the aggregated revenues of the water utility providers declined by over 10 billion HUF, while their costs increased or remained the same. These changes turned the earnings of the sector on the basic operational level into negative in 2013. Most of the providers avoided operational losses due to the positive results of their other activities (KPMG 2015).

These findings were also supported by the survey. Many decision makers expressed concerns over and reported the lack of available funds for asset management, reconstruction and replacement. The ratio of funds for reconstruction and replacement compared to revenue from tariffs was reported extremely low compared to other European countries. This is a serious problem concerning the long term sustainability of the infrastructure, especially if we consider that a large part of the water utility assets are reaching the end of their expected life time in the next decade. 


\subsection{Organizational structure and efficiency}

It is important to note that many of the current negative effects and deteriorations in quality and efficiency perceived by the executives of the water service providers are not uncommon when organizations are undergoing fundamental change. Theories examining the effects of structural change say that any positive effects following reorganizational change can take a considerable time to manifest due to the impact caused by the disruption of existing management practices and operational processes (Hannan - Freeman 1984; Zajac - Raatz 1993).

Hannan and Freeman (1984) differentiate between changes in 'core' and 'peripheral' organizational characteristics. The disruption of the core organizational characteristics has more severe impacts on short and midterm overall processes and operations. The core characteristics of an organization comprise of its ownership, identity, strategy and overall mission. Lee and Alexander (1999) state that during core changes, routines are altered, working groups are restructured, the combination of resources utilized by the organization is altered and methods of communications change. The organizational and market changes that followed the Act on Water Utility Services impacted the core characteristics of the water utility service providers. It resulted in the changes of identity, ownership, strategy and could be considered especially disruptive to the existing processes and management.

It is believed that the responses with regards to economies of scale, efficiency and quality changes vary greatly, because the water service providers were going through significant operational and structural modifications at the time of the survey, and it had a temporary, but overall disruptive effect on their operation.

\section{CONCLUSION AND RECOMMENDATION}

In summary, it can be concluded that despite the major changes and mergers of the service provider companies, efficiency benefits of economies of scale prevail, however, they can only be perceived to a limited extent at the time of the survey. Thus Hypothesis 1 (the integration of the water utility suppliers and the consolidation of the market results in the improvement of the economies of scale and cost efficiency) midway in the transition and integration process is neither proven nor unequivocally disproven. Hypothesis 2 (the integration will led to service quality improvement) is not proven or disproven either - although the majority of respondents perceived a deterioration in the quality of water supply services, this was not unanimous. Hypothesis 3 (the market consolidation will 
lead to more transparent operations and better management and monitoring) cannot be rejected, as the Hungarian Energy and Public Utility Regulatory Authority (HEA) carries out licensing, supervision, regulatory benchmarking, price regulation, price and tariff preparatory tasks and services.

Due to the nature of organizational inertia and the short, mid and long term effects of core changes it is recommended to carry out this survey post integration, with a special focus on $\mathrm{H} 1$ and $\mathrm{H} 2$. It is also recommended to compare the results of the post integration survey with the current survey analyzed in the scope of this paper.

Further analyses could also be useful to examine the relation of efficiency and maturity of the infrastructure as the integration can have significantly different effects and challenges depending on the age of the technical systems to be integrated. Most probably, this is also an explanation for the relatively high deviation of responses concerning perceived efficiency changes. As one of the most challenging issues is the renewal of the technical systems and financing the necessary investments for this task, the patterns of reconstruction needs at different settlement sizes, in water and wastewater sectors along with other parameters should also be further investigated. Such analysis could provide useful information for tariff setting in order to better enforce solidarity, ease financial burden of water utility services at social scale and achieve long term sustainability of the infrastructure and the water utility services.

The internal operations, processes and efficiencies and the positive effects of economies of scale are predicted to balance out on the long term, however, in order to achieve a real and lasting improvement of cost efficiency of the water utility service, the integration of the technical systems needs to follow the concentration of the provider companies, together with further rationalization of the business processes. Furthermore, the external concerns of the legislative environment and financial difficulties of the water suppliers remain. Water utility services are currently provided on decreasing tariffs, while requirements and the financial burden of provider companies are increasing.

The managers of the service providers stay expectant and willing to take actions in order to further efficiency improvement, however, financial obstacles of the necessary investment needs should be eliminated and financial stability of the service provider companies should be restored. Professional and rational tariff setting, based on the real costs, taking into account the real reconstruction and investment needs can be one powerful tool in this task and could also moderate differences between tariff levels in the country in line with the principle of solidarity. 


\section{REFERENCES}

Bod, P. A. (2012): Non-Conventional Economic Policy Measures - Hungarian Style. Hungarian Review 1: 16-23.

García-Sánchez, I. M. (2006): Efficiency Measurement in Spanish Local Government: The Case of Municipal Water Services. Review of Policy Research 23(2): 355-371.

Hannan, M. - Freeman, J. (1984): Structural Inertia and Organizational Change. American Sociological Review 49: 149-164.

IDEA (2013): Magyar Nemzeti Víziközmü-rendszer. A rezsicsökkentés állatorvosi lova [Hungarian National Public Water Utility - The Veterinary Horse of the National Tariff Reduction]. https:// docplayer.hu/5213436-Magyar-nemzeti-vizikozmu-rendszer-a-rezsicsokkentes-allatorvosilova.html, accessed 16/05/2019

Kaderjak, P. (2014): The Hungarian Sector Reform. https://rekk.hu/downloads/events/2014_ danube_region_vienna_kaderjak.pdf, accessed 18/09/2018.

KPMG (2015): A magyar víziközmü ágazat bemutatása - Átfogó tanulmány [The Introduction of the Hungarian Water Utility Sector - Comprehensive Study]. http://www.maviz.org/system/ files/kpmg-maviz_vizikozmu_agazati_helyzetkep_20150513.pdf, accessed 18/09/2018.

Lee, S. D. - Alexander, J. (1999): Managing Hospitals in Turbulent Times: Do Organizational Changes Improve Hospital Survival? Health Services Research 34: 923-946.

Renzetti, S. - Dupont, D. (2009): Measuring the Technical Efficiency of Municipal Water Suppliers: The Role of Environmental Factors. Land Economics 85(4): 627-636.

Szalóki, S. (2015): Experiences of the Hungarian Water Sector Reform from the Regulatory Point of View. http://maszesz.hu/tudastar/experiences-of-the-hungarian-water-sector-reform-fromthe-regulatory-point-of-view, accessed 16/05/2019.

The World Bank Group (2015): Water and Wastewater Services in the Danube Region. http://sos. danubis.org/files/File/SoS_Report.pdf, accessed 18/09/2018.

Tupper, H. C. - Resende, M. (2004): Efficiency and Regulatory Issues in the Brazilian Water and Sewage Sector: An Empirical Study. Utilities Policy 12(1): 29-40.

Ungvári, G. - Koskovics, É. (2011): Áttekintés a magyar víziközmü-ágazatról [Overview of the Hungarian Water Utility Sector]. In: Valentiny, P. - Kiss, F. L. - Nagy, C. I. (eds): Verseny és Szabályozás [Competition and Regulation]. Budapest: MTA KRTK.

Zajac, E. - Raatz, M. (1993): A Diametric Forces Model of Strategic Change: Assessing the Antecedents and Consequences of Restructuring in the Higher Education Industry. Strategic Management Journal 14(S1): 83-102.

Zschille, M. - Walter, M. (2011): The Performance of German Water Utilities: A (Semi)-Parametric Analysis. Applied Economics 44(29): 3749-3764.

Open Access. This is an open-access article distributed under the terms of the Creative Commons Attribution 4.0 International License (https://creativecommons.org/licenses/ by/4.0), which permits unrestricted use, distribution, and reproduction in any medium, provided the original author and source are credited, a link to the CC License is provided, and changes - if any - are indicated. (SID_1) 